\title{
The Phytochemical Screening and Antibacterial Activity of the Leaves of CombretumPaniculatum (Vent) SolaniumMacrocarpon (L) and CatharanthusRoseus (L) G. Don.
}

\author{
${ }^{1}$ Osuagwu, G. G. E. ${ }^{2}$ Nwoko, N \\ Department of plant Science and Biotechnology,Michael Okpara University of Agriculture, Umudike, \\ UmuahiaAbia State Nigeria
}

\begin{abstract}
The phytochemical screening and the antibacterial activity of the leaves of Combretum paniculatum, Solanium macrocarpon and Catharanthus roseus were carried out to ascertain their medicinal potential. Ethanolic extracts of the leaves of the plants were tested on Escherichia coli, Staphylococcus aureus, Salmonella typhi and Pseudomonas aeruginosa using the agar well diffusion method.The investigations showed that the leaves of the three plant species contained alkaloids, flavonoids, phenols, saponin, steroids and tannins in varying proportions. Results obtained also indicated that the percentage phytochemical contents are as follows: Alkaloids (2.41 - 2.70), Phenols (0.052 - 0.108), flavonoids $(0.90-1.74)$, saponins $(0.43-1.65)$, steroids (0.042-0.18) and tannins $(0.174-0.295)$. Generally, the most prominent phytochemical in the leaves of the plants was alkaloids. The Ethanolic extracts of the leaves of all the plants inhibited the growth of the human bacterial pathogens used in the study. The inhibition zone ranged from 6.67 to $14.70 \mathrm{~mm}$. The inhibition concentration (MIC) values of the extracts ranged from 2.33 to $14.67 \mathrm{mg} / \mathrm{ml}$. The results of the study reveal the medicinal potential of the leaves of the plants and that they can be utilized in treatment of some bacterial infections.
\end{abstract}

Key words: Antibacterial activity, Inhibition zone, Phytochemicals, Catharanthus roseus, Combretum paniculatum, and Solanium macrocarpon.

\section{Introduction}

Plants have been known to play important role in the maintenance of good health. Research reports have indicated that plants are playing significant role in maintenance of good health $[9 ; 36]$. Kamba and Hassan [22],observed that the bases of many modern pharmaceuticals used today are plants and plant based products. Plants have been utilized for treatment of diseases worldwide. The report of WHO [46], indicated that estimated $80 \%$ of world populations depend on plant based medicine for their health care. In Nigeria and other African countries, indigenous people traditionally use a wide range of plants as source of food and medicine. These plants therefore constitute a reservoir of a wide variety of compounds which show some medicinal and nutritive properties, thus are used as spices, food or medicine [10;32].

The use of plants and plant based products to societal health need stems from the fact that indiscriminate use of commercial antimicrobial drugs commonly utilized in the treatment of infectious diseases has led to the development of multiple drug resistance [16],theadverse effect on host, associated with the use of conventional antibiotics [16],the safety and cost effectiveness of the use of plants in traditional as well as in modern medicine [24], and high cost, adulteration and increasing toxic side effects of these synthetic drugs[41].Thus there has been the need to develop alternative antimicrobial drugs from medicinal plants for the treatment of infectious diseases;because antimicrobials of plant origin have been found to have enormous therapeutic potential [45]. Furthermore, the studies by Perumalsamy and Ignacimuthu [39] showed that antimicrobials from plant origin are effective in the treatment infectious diseases and on the other hand simultaneously mitigates many of the side effects that are linked with synthetic antimicrobials.

Many of these indigenous plants contain bioactive compounds that exhibit physiological activities against bacteria and other microorganisms and are also used as precursors for the synthesis of useful drugs. Thus the usefulness of these plant products in medicine is due to the presence of bioactive substances such as alkaloids, tannins, flavonoids, phenolic compounds, steroids, resins and other secondary metabolites which they contain and are capable of producing definite physiological action in the body [5; 11].

Phytochemicals are known to carry out important medicinal roles in the body. Alkaloids are known to have a powerful effect on animal physiology. They play some metabolic role and control development in living system [9]. They are also used as starting materials in the manufacture of steroidal drugs and carry out protective function in animals, thus are used as medicine especially steroidal alkaloids [25]. Isolated pure plant alkaloids and their synthetic derivatives are used as basic medicinal agent for their analgesic, antispasmodic and bacteridal effect [27]. Flavonoids are known to carry out antioxidant, protective effects and inhibit the initiation, 
promotion and progression of tumors [23; 29]. Isoflavones, some kind of flavonoids are phytoestrogen which effectively modulate estrogen levels in human [30]. A type of flavonoid anthocyanin helps in reducing the incidence of cardiovascular diseases, cancer, hyperlipidemias and other chronic diseases [7]. Phenolic compounds in plants are potentially toxic to the growth and development of pathogens [42]. Research reports also show that phenolic compounds carry out potent antioxidant activity and wide range of pharmacologic activities which include anti- cancer, antioxidant and platelet aggregation inhibition activity [40]. Saponins play essential roles in medicine. These include serving as expectorant and emulsifying agent [12] and having antifungal properties [35]. Tannins are reported to inhibit pathogenic fungi [6]. They are also associated with many human physiological activities such as stimulation of phargocytic cells and host mediated tumor activity and a wide range of infective actions [18]. Steroid containing compounds are of importance in pharmacy due to their role in sex hormones [28]. Steroids such as equine estrogen are implicated in the reduction of risks of coronary heart and neurodegenerative diseases in healthy and young postmenopausal women [38]. At low concentration tannins show antimicrobial, cytotoxic and astringent properties [20;47].

The phytochemical screening of some plants has been carried out and are found to be rich in alkaloids, phenols, flavonoids, saponins, steroids, and tannins [31; 34]. Studies have also reported the antimicrobial activities of plant leaves and other parts $[24 ; 33 ; 34]$.These plants are therefore used in the treatment of many diseases such as rheumatism, diarrhea, malaria, elephantiasis, cold, obesity, dysentery, gonorrhea and others [1; 13].

Combretum paniculatum belongs to the Combretacea family. It is ascadent shrub with tailing branches. The leaves of the plants are used in folk medicine for the treatment of diseases such as stomach pain and diarrhea [2].

Solanium macrocarpon belongs to the Solanaceae family. It is a warm season crop vegetable with thin rightly wrinkled leaves that are commonly eaten green. It grows up to the height of $1-1.5 \mathrm{~m}$. Leaves are used for the treatment of bronchitis, itching of the body, asthma and wounds. Seeds are used in treating toothache [26].

Catharanthus roseus belongs to Apocynaceae family. It is an evergreen sub shrub or herbaceous plant growing to $1-1.5 \mathrm{~m}$ tall. The leaf extracts of $\mathrm{C}$. roseus are used in traditional medicine for the of diabetes, malaria, high blood pressure, Hodgkin's disease, sore throat and mouth ulcers [19].

The objectives of this research are to ascertain the phytochemical contents and the antibacterial activity of the leaves of these plants in order to see the possibility of their exploitation and use in the treatment of diseases.

\subsection{Plant samples}

\section{Materials and methods}

The leaves of Combretum paniculatum were obtained from a bush forest in Old -Umuahia, Umuahia South Local Government Area Abia State. Solanium macrocarpon leaves were obtained from the premises of Michael Okpara University of Agriculture Umudike, Umuahia, Abia State Nigeria. While the leaves of Catharanthus roseus were obtained from Ehimiri Housing Estate Umuahia, Abia State Nigeria. The leaves were identified by the taxonomic unit of the Department of Plant Science and Biotechnology Michael Okpara University of Agriculture, UmudikeUmuahiaAbia State Nigeria.

The leaves were oven dried using the Selecta model $150-900 \mathrm{~L}$ oven at $65^{\circ} \mathrm{C}$ for 24 hours and ground into powder using Thomas Willey milling machine. Powdered samples were stored in sample bottles and stored in the laboratory of plant Science and Biotechnology, Michael Okpara University of Agriculture UmudikeUmuahia, Abia State, Nigeria to be used for the tests.

\subsubsection{Determination of the phytochemical content of the plant samples}

Both qualitative and quantitative tests were carried out on the samples to determine the presence and the amount of the phytochemicals in the powdered samples.

\subsubsection{Qualitative analysis of the plant samples}

\section{Test for presence of alkaloids.}

The presence of alkaloids in each sample was investigated using the method described by Harborne [17].

An alcoholic extract was used and obtained by dispersing $2 \mathrm{~g}$ of the powered sample in $10 \mathrm{ml}$ of ethanol. The mixture was through shaken before filtering using Whatman No (40) filter paper. $2 \mathrm{ml}$ of the filtrate was added into a test tube and 3 drops of pirovic acid was mixed with it. The formation of light green colouration indicates presence of alkaloid.

\section{Test for the presence of flavonoid}

The determination of presence of flavonoid in the sample was carried out using the acid alkaline test described by Harborne [17].

$2 \mathrm{ml}$ of the aqueous extract was added into a test -tube and a few drops of Bench Concentrated ammonia $\left(\mathrm{NH}_{4}\right)$ were also added. The formation of a yellow colouration shows presence of flavonoid. Confirmatory test was 
carried out by adding few drops of concentrated hydrochloric (HCL) into the yellow solution which turned colourless.

Test for the presence of phenols.

The presence of phenols in the sample was carried out using the Harborne [17] methods.

The fat free sample was boiled with $50 \mathrm{ml}$ of ether for 15 minutes. $5 \mathrm{ml}$ of the extract was pipette into a $50 \mathrm{ml}$ flask and $10 \mathrm{ml}$ of distilled water added into it. $2 \mathrm{ml}$ of ammonia hydroxide solution and $5 \mathrm{ml}$ of concentrated amyl alcohol were also added. The mixture was allowed to react for 30 minutes for colour development.

\section{Test for the presence of saponin}

The presence of saponins in the samples was determined using Harborne [17] method.

Two tests were involved in the investigation, the froth test and emulsion test.

In the froth test, $2 \mathrm{ml}$ of the aqueous extract was mixed with $5 \mathrm{ml}$ of distilled water in a test tube. The mixture was shaken vigorously. A stable froth on standing indicates the presence of saponins.

In the emulsion test, 3 drops of groundnut oil, was added to the aqueous extract mixed with $5 \mathrm{ml}$ of distilled water and shaken well. Formation of emulsion indicates the presence of saponins.

\section{Test for the presence of tannin}

The presence of tannins in the samples was determined using the method described by Harborne [17].

$2 \mathrm{ml}$ of the aqueous extract filtrate and $3 \mathrm{ml}$ distilled water was put into a test tube. A few drops of $0.1 \%$ ferric chloride was added to the mixture. The formation of a very dark precipitate indicated presence of tannin.

\subsubsection{Quantitative determination of the phytochemical constituents of the plant samples Alkaloid determination}

The determination of the concentration of alkaloid in the leaves of the plants was carried out using the alkaline precipitation gravimetric method described by Harborne [17].

$5 \mathrm{~g}$ of the powdered sample was soaked in $20 \mathrm{ml}$ of $10 \%$ ethanolic acetic acid. The mixture was stood for four (4) hours at room temperature. Thereafter, the mixture was filtered through Whatman filter paper (No 42). The filtrate was concentrated by evaporation over a steam bath to $1 / 4$ of its original volume. To precipitate the alkaloid, concentrated ammonia solution was added in drops to the extract until it was in excess. The resulting alkaloid precipitate was recovered by filtration using previously weighed filter paper. After filtration, the precipitate was washed with $9 \%$ ammonia solution and dried in the oven at $60^{\circ} \mathrm{C}$ for 30 minutes, cooled in a dessicator and reweighed. The process was repeated two more times and the average was taken. The weight of alkaloid was determined by the differences and expressed as a percentage of weight of sample analyzed as shown below.

Where:-

$$
\% \text { Alkaloid } \begin{gathered}
= \\
\text { Weight of sample }
\end{gathered} \frac{\mathrm{W}_{2}-\mathrm{W}_{1}}{1} \quad \underline{100}
$$

$$
\begin{aligned}
& \mathrm{W}_{1}=\text { weight of filter paper } \\
& \mathrm{W}_{2}=\text { weight of filter paper }+ \text { alkaloid precipitate }
\end{aligned}
$$

\section{Flavonoid determination.}

The flavonoid content of the leaves of the plant was determined by the gravimetric method as was described by Harborne [17].

$5 \mathrm{~g}$ of the powdered sample was placed into a conical flask and $50 \mathrm{ml}$ of water and $2 \mathrm{ml} \mathrm{HCl}$ solution was added. The solution was allowed to boil for 30 minutes. The boiled mixture was allowed to cool before it was filtered through Whatman filter paper (No 42). 10ml of ethyl acetate extract which contained flavonoid was recovered, while the aqueous layer was discarded. A pre weighed Whatman filter paper was used to filter second (ethyl-acetate layer), the residue was then placed in an oven to dry at $60^{\circ} \mathrm{C}$. It was cooled in a dessicator and weighed. The quantity of flavonoid was determined using the formular.

Where:-

$\%$ Flavonoid $=$
$\quad$ Weight of Sample
$\quad 1$

$$
\begin{aligned}
& \mathrm{W}_{1}=\text { Weight of empty filter paper } \\
& \mathrm{W}_{2}=\text { Weight of paper }+ \text { Flavonoid extract }
\end{aligned}
$$

\section{Determination of phenols}

The concentration of phenols in the leaves of the leaves of the plants was determined using the folincioCaltean colorimetric method described by Pearson [37].

$0.2 \mathrm{~g}$ of the powdered sample was added into a test tube and $10 \mathrm{ml}$ of methanol was added to it and shaken thoroughly the mixture was left and to stand for 15 minutes before being filtered using Whatman (No42) filter paper. I $\mathrm{ml}$ of the extract was placed in a text-tube and $\mathrm{I} \mathrm{ml}$ folin-cioCaltean reagent in $5 \mathrm{ml}$ of distilled water 
was added and color was allowed to develop for about 1 to 2 hours at room temperature. The absorbance of the developed colour was measured at $760 \mathrm{~nm}$ wave. The process was repeated two more times and an averaged taken. The phenol content was calculated thus.

$\%$ Phenol $=100 / \mathrm{w} \times \mathrm{AU} / \mathrm{AS} \times \mathrm{C} / 100 \mathrm{x} \mathrm{VF} / \mathrm{VA} \times \mathrm{D}$

Where,

$\mathrm{W}=$ weight of sample analyzed

$\mathrm{AU}=$ Absorbance of test sample

$\mathrm{AS}=$ Absorbance of standard solution

$\mathrm{C}=$ concentration of standard in $\mathrm{mg} / \mathrm{ml}$

$\mathrm{UF}=$ total filtrate volume

$\mathrm{VA}=$ Volume of filtrate analyzed

$\mathrm{D}=$ Dilution factor were applicable

\section{Determination of saponins}

The saponin content of the sample was determined by double extraction gravimetric method [17].

$5 \mathrm{~g}$ of the powered sample was mixed with $50 \mathrm{ml}$ of $20 \%$ aqueous ethanol solution in a flask. The mixture was heated with periodic agitation in water bath for 90 minutes at $55^{\circ} \mathrm{C}$; it was then filtered through what man filter paper (No42). The residue was extracted with $50 \mathrm{ml}$ of $20 \%$ ethanol and both extracts were poured together and the combined extract was reduced to about $40 \mathrm{ml}$ at $90^{\circ} \mathrm{C}$ and transferred to a separating funnel where $40 \mathrm{ml}$ of diethyl ether was added and shaken vigorously. Separation was by partition during which the ether layer was discarded and the aqueous layer reserved. Re extraction by partitioning was done repeatedly until the aqueous layer become clear in color. The saponins were extracted, with $60 \mathrm{ml}$ of normal butanol. The combined extracts were washed with $5 \%$ aqueous sodium chloride $(\mathrm{NaCl})$ solution and evaporated to dryness in a preweighed evaporation dish. It was dried at $60^{\circ} \mathrm{C}$ in the oven and reweighed after cooling in a dessicator. The process was repeated two more times to get an average. Saponin content was determined by difference and calculated as a percentage of the original sample thus

Where

$$
\underset{\text { Wt of sample }}{\text { Saponin }} \frac{\mathrm{W}_{2}-\mathrm{W}_{1}}{1} \times \quad \text { x }
$$

$$
\begin{aligned}
& \mathrm{W}_{1}=\text { weight of evaporating dish } \\
& \mathrm{W}_{2}=\text { weight of dish }+ \text { sample } \\
& \text { Steroid determination }
\end{aligned}
$$

The steroid content of the leaves of the plants was determined using the method described by Harborne [17]. $5 \mathrm{~g}$ of the powdered sample was hydrolysed by boiling in $50 \mathrm{ml}$ hydrochloric acid solution for about 30 minutes. It was filtered using Whatman filter paper (N042), the filtrate was transferred to a separating funnel. Equal volume of ethyl acetate was added to it, mixed well and allowed separate into two layers. The ethyl acetate layer (extract) recovered, while the aqueous layer was discarded. The extract was dried at $100^{\circ} \mathrm{C}$ for 5 minutes in a steam bath. It was then heated with concentrated amyl alcohol to extract the steroid. The mixture becomes turbid and a reweighed Whatman filter paper (N042) was used to filter the mixture properly. The dry extract was then cooled in a dessicator and reweighed. The process was repeated two mere times and an average was obtained.

The concentration of steroid was determined and expressed as a percentage thus

Where,

$$
\% \text { Steroid } \quad=\quad \frac{\mathrm{W}_{2}-\mathrm{W}_{1}}{1} \times \frac{100}{\text { Wt of sample }}
$$

$\mathrm{W}_{1}=$ weight of filter paper.

$\mathrm{W}_{2}=$ weight of filter paper + steroid

\section{Tannin determination}

The tannin content of the leaves of the plants was determined using the Folin Dennis spectrophotometric method described by Pearson [37].

$2 \mathrm{~g}$ of the powered sample was mixed with $50 \mathrm{ml}$ of distilled water and shaken for 30 minutes in the shaker. The mixture was filtered and the filtrate used for the experiment. $5 \mathrm{ml}$ of the filtrate was measured into $50 \mathrm{ml}$ volume flask and diluted with $3 \mathrm{ml}$ of distilled water. Similarly $5 \mathrm{ml}$ of standard tanuric acid solution and $5 \mathrm{ml}$ of distilled was added separately. $1 \mathrm{ml}$ of Folin- Dennis reagent was added to each of the flask followed by $2.5 \mathrm{ml}$ of saturated sodium carbonate solution. The content of each flask was made up to mark and incubated for 90 minutes at room temperature. The absorbance of the developed colour was measured at 760.nm wave length with the reagent blank at zero. The process was repeated two more times to get an average. The tannin content was calculated as shown below

$$
\% \text { tannin }=100 / \mathrm{W} \times \mathrm{AY} / \mathrm{AS} \times \mathrm{C} / 100 \times \mathrm{VF} / \mathrm{VA} \times \mathrm{D}
$$

Where, 
$\mathrm{W}=$ weight of sample analysed

$\mathrm{AY}=$ Absorbance of the standard solution

$\mathrm{C}=$ Concentration of standard in $\mathrm{mg} / \mathrm{ml}$.

$\mathrm{VA}=$ volume of filtrate analysed

$\mathrm{D}=$ Dilution factor where applicable

\subsubsection{Determination of antimicrobial activity \\ 2.3.1 Preparation of plant extracts.}

The ethanolic extracts of the leaves of the plants were prepared using the method of Ijeh et al., [21].

Fifty grams of the powdered sample were soaked in $200 \mathrm{ml}$ of absolute ethanol and allowed to stand for 24 hours. They were filtered using WhatmanNo1 Filter Paper. The filtrates were evaporated to dryness with rotary evaporator at $40^{\circ} \mathrm{C}$ to thick residues. The residues were dissolved in deionised water to obtain the desired plant extracts for the antimicrobial tests.

\subsubsection{Preparation of Innocular}

The human pathogens; Escherichia coli, Staphylococcus aureus; Salmonella typhi and Pseudomonas aeruginosa used in the research were obtained from the stock culture of the Microbiology Laboratory, Federal Medical Centre, Umuahia, Abia State, Nigeria as clinical isolates. These were cultured and identified by Dr. O.D. Omodamiro of the Department of Microbiology Michael Okpara University of Agriculture UmudikeUmuahiaAbia State Nigeria.Viability test of each isolate was carried out by resuscitating the organism in buffered peptone broth and thereafter sub-cultured into nutrient agar medium and incubated at $37^{\circ} \mathrm{C}$ for 24 hours.

\subsubsection{Antimicrobial activity test}

The sensitivity of the test organism to the ethanolic extracts of the leaves of C. paniculatum, S. macrocarpon and $C$. roseus was carried out using the diffusion method described by Ebi and Ofoefule [8].

$20 \mathrm{ml}$ of the molten nutrient agar was seeded with $0.2 \mathrm{ml}$ of broth culture of the test organisms in sterile Petridishes. The Petri dishes were rotated slowly to ensure a uniform distribution of the organisms. They were left to solidify and dish cups of $8.0 \mathrm{~mm}$ diameter were made in the agar using a sterile Pasteur pipette. The Petridishes were allowed to stand for about 30minutesat room temperature to allow for the proper diffusion of the extracts to take place. The plates were then incubated at $37^{\circ} \mathrm{C}$ for 24 hours. The zones of inhibition in millimetres were measured and recorded.

The test was carried out in the Laboratory of the Department of Plant Science and Biotechnology, Michael Okpara University of Agriculture, Umudike, Umuahia, Abia State, Nigeria.

\subsubsection{Minimum Inhibitory Concentration (MIC) Test}

The agar dilution method described by Baron and Finegold [4] was used to ddetermined the minimum inhibitory concentration.

Six grams of nutrient agar were dissolved in $250 \mathrm{ml}$ of distilled water in a conical flask. After sterilization, the nutrient agar was poured into sterilized Petri dishes to solidify. The microorganisms were introduced into the wells using swap sticks. Extracts of $5 \mathrm{mg} / \mathrm{ml}, 15 \mathrm{mg} / \mathrm{ml}, 20 \mathrm{mg} / \mathrm{ml}$ and $25 \mathrm{mg} / \mathrm{ml}$ were made from the original test samples. The Petri dishes were then placed in the incubator at $37^{\circ} \mathrm{C}$ for 24 hours. The inhibition zones in millimetres weremeasured and recorded.

\subsection{Statistical Analysis}

The tests were carried out in triplicate; data obtained were analyzed using mean and standard deviation.

\section{Results}

The results of the phytochemical screening and the antibacterial activity of the leaves of Combretum paniculatum, Solanium macrocarpon and Catharanthus roseus are summarized in tables $1-4$.

The phytochemical screening of the leaves of C. paniculatum, S. macrocarpon and C. roseus indicated that they contain alkaloids, flavonoids, phenols, saponin, steroids and tannins (table 1). The presence of these phytochemicals in the leaves of these plants confers on them their medicinal values $[6 ; 15]$.The pharmaceutical and therapeutic values of plants and their products is as a result of the presence of these phytochemicals in them [5; 11]. Presence of these phytochemicals in the leaves of other plants has been reported [31; 34]. The percentage concentration of alkaloids, flavonoids, phenols, saponin, steroids and tannins in the leaves of the plants is summarized in table 2 . The phytochemical content of the leaves of the plants are as follows: alkaloid $(2.02-2.70 \%)$, flavonoid $(0.90-1.74 \%)$, phenols $(0.052-1.09 \%)$, saponin $(0.43-1.65 \%)$, steroids $(0.042-$ $0.18 \%)$ and tannins $(0.174-0.295 \%)$. The results obtained show that the leaves of these plants have appreciable quantity of these phytochemicals, hence their medicinal value. Generally, the leaves of the plants had more alkaloids than any other phytochemicals. Alkaloids are known to play some metabolic roles and control 
development in living system and also have protective roles in animals [9]. The least occurring phytochemicals in the leaves of the plants were phenols and steroids. The leaves of $S$. macrocarpon had more flavonoids and saponins $(0.98 \% ; 1.60 \%)$ than C. roseus $(0.90 \% ; 1.05 \%)$ and C. paniculatum $(0.174 \% ; 0.43 \%)$. Differences in the concentration of phytochemicals in plant leaves were also observed by other researchers [14; 27].

The results of the antibacterial activity of the Ethanolic extracts of the leaves of C. paniculatum, S. macrocarpon and C. roseus on Escherichia coli, Staphylococcus aureus, Salmonella typhi and Pseudomonas aeruginosa are summarized in tables 3 and 4. The Ethanolic extracts of the leaves of C. paniculatum, S. macrocarpon and C. roseus had antibacterial activity on all the human pathogens used in the investigation (table 3 ). The inhibition zone ranged from $6.67-14.70 \mathrm{~mm}$. Generally, extracts of the leaves of $C$. paniculatum had the highest inhibitory effect on the growth of the test pathogens when compared to those of the leaves of $S$. macrocarpon and $C$. roseus (table 3 ). The leaf extracts of $C$. paniculatum, had the highest inhibitory effect on $E$. coli $(14.00 \mathrm{~mm})$, when compared to those of C. roseus $(8.60 \mathrm{~mm})$ and $S$. macrocarpon $(6.67 \mathrm{~mm})$. on the other hand, the highest inhibitory effect on $S$. typhi was caused by the leaf extracts of $S$. macrocarpon $(14.30 \mathrm{~mm})$ followed by those of C. paniculatum $(11.30 \mathrm{~mm})$ and $C$. roseus $(10.00 \mathrm{~mm})$. The pharmaceutical and therapeutic values of the leaves of these plants stem from their ability to inhibit the growth of these human pathogens. Research reports indicate that the leaves of the plants are used in the treatment of diseases $[2 ; 15 ; 19 ; 26]$.

The antimicrobial activity of the leaves of other plants has been reported $[3 ; 24 ; 33 ; 34]$. The abilityof the extracts to inhibit the growth of the test pathogens might be as a result of the presence of bioactive substances (alkaloids, flavonoids, phenols, saponins, steroids and tannins) in their leaves [5;31]. There seems to be a correlation between the concentration of the extracts and their ability to inhibit the growth of the pathogens. The rate of the inhibition of the growth of the pathogens increased with the increase in the concentration of the extracts (table 4). This trend was also observed by some other researchers [43; 44].The minimum inhibitory concentration (MIC) of the Ethanolic extracts of the leaves of the plants used in the study ranged from 2.33 to $14.67 \mathrm{mg} / \mathrm{ml}$ (table 4).

\section{Conclusion}

This investigation showed that the leaves of C. paniculatum, S. macrocarpon and C. roseus have appreciable amount of these phytochemicals and have antibacterial activity on the human pathogens used in the study. Indicating that they are of high medicinal value thus could be exploited to be used in the formulation of cheap alternative antimicrobial drugs. These drugs could then be used to cure and control human infectious diseases.

Table 1:The qualitative analysis of the phytochemicals in the leaves of Combretum paniculatum, Catharanthusroseus and Solaniummacrocarpon

\begin{tabular}{lccccc}
\hline Plant species & Alkaloids & Flavonoids & Phenols & Saponins & Steroids \\
\hline Combretumpaniculatum & + & + & + & + & Tannins \\
Catharanthusroseus & + & + & + & + & + \\
Solaniummacrocarpon & + & + & + & + & + \\
\hline
\end{tabular}

Key: + = presence

$$
\text { - = absence }
$$

Table 2: The percentage alkaloids, flavonoids, phenols, saponins, steroids and tannins content of the leaves of $C$, paniculatum, $C$. roseus and $S$. macrocarpon.

\begin{tabular}{|c|c|c|c|c|c|c|}
\hline Plant species & Alkaloids & Flavonoids & Phenols & Saponins & Steroids & Tannins \\
\hline C. paniculatum & $2.01 \pm 0.02$ & $0.174 \pm 0.40$ & $0.052 \pm 0.04$ & $0.43 \pm 0.02$ & $0.042 \pm 0.04$ & $0.174 \pm 0.40$ \\
\hline C. roseus & $2.01 \pm 0.05$ & $0.90 \pm 0.02$ & $0.08 \pm 0.06$ & $1.05 \pm 0.05$ & $0.184 \pm 0.06$ & $0.304 \pm 0.05$ \\
\hline S. macrocarpon & $2.70 \pm 0.07$ & $0.98+0.03$ & $0.062+0.05$ & $1.60 \pm 0.07$ & $0.08 \pm 0.01$ & $0.295 \pm 0.01$ \\
\hline
\end{tabular}

Table 3: The antibacterial activity of the Ethanolic extracts of the leaves of $C$. paniculatum, $C, \quad$ roseus and $S$. macrocarpon on Escherichia coli, Staphylococcus aureus, Salmonella typhi andPseudomonas aeruginosa

\begin{tabular}{llll}
\hline Pathogenic organisms & $\begin{array}{l}\text { C.paniculatum } \\
\text { Zone }\end{array}$ & $\begin{array}{l}\text { C.roseus } \\
\text { Of }\end{array}$ & $\begin{array}{l}\text { S. macrocarpon } \\
\text { Inhibition (mm) }\end{array}$ \\
\hline E. coli & $14.00 \pm 6.56$ & $8.60 \pm 2.08$ & $6.67 \pm 2.31$ \\
S. aureus & $14.70 \pm 6.11$ & $9.33 \pm 3.79$ & $11.00 \pm 5.19$ \\
S. typhi & $11.30 \pm 3.21$ & $10.00 \pm 4.17$ & $14.30 \pm 7.63$ \\
P. aeruginosa & $14.30 \pm 6.63$ & $9.33 \pm 2.85$ & $13.00 \pm 6.85$ \\
\hline
\end{tabular}


Table 4: The minimum inhibitory concentration $(\mathrm{mg} / \mathrm{ml})$ of the Ethanolic extracts of the leaves of $C$. paniculatum, C. roseus and S. macrocarpon on E. coli, S. aureus, S. typhi and P. aeruginosa

\begin{tabular}{|c|c|c|c|c|c|c|c|c|c|c|c|c|c|c|c|}
\hline \multirow{2}{*}{$\begin{array}{l}\text { Pathogenic } \\
\text { Organism } \\
\text { MIC } \\
\end{array}$} & \multicolumn{5}{|c|}{ C. paniculatum } & \multicolumn{5}{|c|}{ C. roseus } & \multicolumn{5}{|c|}{ S. macrocarpon } \\
\hline & 12.5 & 25 & 50 & 100 & 200 & 12.5 & 25 & 50 & 100 & 200 & 12.5 & 25 & 50 & 100 & 200 \\
\hline$\overline{E . c o l i}$ & 6.0 & 7.3 & 8.3 & 13.0 & 13,3 & 0.6 & 2.7 & 3.0 & 4.0 & 4.7 & 6.3 & 10.0 & 11.0 & 14.0 & 16.3 \\
\hline S.aureus & 7.7 & 10.3 & 11.0 & 11.7 & 14.3 & 14.3 & 18.7 & 18.3 & 20.7 & 24,0 & 10,0 & 11.3 & 11.3 & 11.6 & 13.3 \\
\hline S. typhi & 5.3 & 9.3 & 10.7 & 12.0 & 14.7 & 6.0 & 10.3 & 15.3 & 15.7 & 18.3 & 2.3 & 4.6 & 8.0 & 11.3 & 12.7 \\
\hline P. aeruginosa & 4.0 & 4.3 & 11,0 & 12.6 & 13,7 & 4.3 & 9.0 & 13.3 & 17.3 & 22.5 & 2.3 & 3.0 & 7.3 & 10.0 & 11.3 \\
\hline
\end{tabular}

MIC = Minimum inhibitory Concentration

\section{References}

[1]. G.C.Akuodor, M. S. Idris-Usman, C. C. Mbah, U. A.Megiwar, J. I. Akpan, T. C. Ugwu, D. O.Okoroafor,andU. A. Osunkwo. Studies of anti-ulcer,analgestic and antipyretic properties of ethanolic leaf extract of Gongonemalatifoliumin rodents. African Journal of Biotechnology, 9(5), 2010,2316-2321.

[2]. M. Arbonnier. Trees, shrubs and lianas of West African dry zones. (CIRAD MARGRAF publishers, GMBH. AJ. Wageningen, The Netherland, 2004, $573 \mathrm{pp}$ ).

[3]. H. Arshad, H. Shadma, I.Iffat and Sarfara-Hussein.Antibacteria activity of the leaves of Cocciniaindica(W and A)W of India.AdvancesinBiologicalResearch4(5), 2010, 241-248.

[4]. J. E. Baron and S. M. Finegold. Methods for testing antimicrobial effectiveness.In Bailey.ScottsDiagnostic Microbiology, Mossy C. V.(ed.)Missouri, 1990) pp 171-194.

[5]. J. U. Bishnu, L. Sunil and S.AnuJa.Antibacterial properties of different medicinal plants; Ocimum sanctum, Cinnamomumzeylanicum, Xanthoxylimarimatum and Origanummasorana. KathmanduUniversity Journal of Science, Engineering and Technology,5, 2009, 143-150.

[6]. I. H.Burkill. The Useful Plants of West Tropical Africa (Vol. 3 Families J-L).(Royal Botanical Garden,Kew, 1995) 605 pp.

[7]. S.de - Pascual - Teresa and Sanchez, Ballesta. Anthocyanins: From Plants to Health, 17(2), 2008,281 - 289.

[8]. G. C. Ebiand S.I. Ofoefule. Investigation into the folkloric antimicrobial activities of Landolphiaowerriance.Phytotherapeutic Research, 11, 1997,147-151.

[9]. H. O.Edeoga and D. O.Eriata.Alkaloid,tannin and saponin contents of some Nigerian medicinal plants. Journal of Medicinal and Aromatic Plant Science, 23, 2001, 244-249.

[10]. H. O,Edeoga, D. E. Okwu and B.O.Mbaebie. Mineral and nutritive value of some Nigerian medicinal plants. JournalofMedicinalandAromaticPlantSciences, 25, $2003 \quad 689$ - 694

[11]. H. O. Edeoga, D. E.Okwu and B. O. Mbaebie. Phytochemical constituents of some Nigerian medicinal plants. African Journal of Biotechnology, 4, 2005, $685-688$.

[12]. H.O.Edeoga, G. G. E. Osuagwu,G. Omosun, B.O. Mbabie and A.S. Onwuka. (2009). Chemical Characteristics and utility of some Rubiaceous medicinal plants. Phytopharmacology and Therapeutic Values. 23, 2009, 79-87.

[13]. E. E. Edet, M. I.Akpanabiatu,A. E.Eno,I. B.Umohand E. H. Itam.Effect of Gongonemalatifoliumcrude extract on some cardiac enzymes of alloxan-induced diabetic rats. African Journal of Biochemistry,3(11), 2009, 366-369.

[14]. D. Ganjewala, S. Sam and K. H. Khan. Biochemical compositions and antibacterial plants with yellow, lavender, red and $\quad$ white flowers. EurAsia Journal of Biological Sciences, 3 (10), 2009, 69-77

[15]. L. S. Gill.Ethnomedicinal uses of plants in Nigeria,(University of Benin press, Benin, Nigeria, 1992) 124pp.

[16]. C. Gupta,P. Amar,G.Ramesh, C. Uriyaand A. Kumari.Antimicrobial activity of some herbal oils against common foodborne pathogens. African Journal of Microbial Research, 2, 2008, 258-261.

[17]. J. B.Harborne. (1984). Phytochemical methods. Second Edition, (Chapman and Hall Ltd., London, 1984), 288pp.

[18]. E.Haslam.Natural polyphenols (Vegetable tannins) as drugs possible mode of action. Journal of Natural Products. 59, 1996, 205 215 .

[19]. V. H.Heywood, R. K. Brummitt, A. Culham and O. Seberg.Flowering plant families ofthe world. (Royal Botanical Gardens, Kew, 2008)

[20]. I. I. Ijeh, O. U. Njokuand E. C. Ekenze. Medicinal evaluation of extracts of Xylopiaaethipica and Ocimumgratissimum. J. of Med. Arm. Plant Sc. 26, 2004, $41-49$.

[21]. I. I.Ijeh, O. D. Omodamiroand I. J. Nwanna. Antimicrobial effects of aqueous and ethanolic fractions of two spices, Ocimumgratissimum and Xylopianetiopica. African Journal of Biotechnology, 4(9), 2005,953 - 956.

[22]. A. S.Kambaand L. G. Hassan.Phytochemical screening and antimicrobialactivities of Euphorbiabalasamifera leaves, stem and root against some pathogenic microorganisms. African Journal of Pharmaceutical Sciences and Pharmacy, 1(1), 2010, 57-64.

[23]. S.Y.Kim, J. H. Kim, S. K. Kim, M. J. Ohandyand M. Y. Jung. Antioxidant activities of selected oriental herb extracts. J. Am. Oil Chem. Soc. 71, $1994633-640$.

[24]. D. K.Koche,D. G. Bhadange and K. D.Kamble. Antimicrobial activity of three medicinal plants. Bioscience Discovery,2(1), 2011, 69-71.

[25]. A. Maxwell, M. Seepersaud,P. Pingal, D. R. Mootoo and W. F. Reynoids. 3-beta amino spirosolane steroidal alkaloids from Solanumtriste. Journal of Natural Products, 58, 1995, 625-628.

[26]. G. Oboh, M. M. Ekperigin, and M. I. Kazeem. Nutritional and haemolytic properties of egg plants (Solaniummacrocarpon) leaves. Journal of Food Composition and Analysis, 18 (2/3), 2008, 153 - 160.

[27]. C. E. Ogukwe, E. E. Oguzie, C. Unaegbu and B. N. Okolue. Phytochemical screening of the leaves of Sansevieratrifasciata J. Chem. Soc. Nigeria, 29(1),2004, $8-10$.

[28]. D. E. Okwu. Evaluation of the chemical composition of indigenous species and flavouring agents. Global Journal of Pure and Applied Sciences, 7(3), 2001, $455-459$.

[29]. D. E.Okwu. The phytochemicals and vitamins contents of indigenous spices of South Eastern, $\quad$ Nigeria. J. Sust. Agric. Environ. 6, 2004. $30-34$.

[30]. D. E. Okwu. and O. D. Omodamiro. (2005). Effects of hexane extract and phytochemical content of Xylopiaaethiopica and Ocimumgratissimum on the uterus of guinea pig. Bio. Research 3(2), $2005 \quad 40-44$. 
[31]. O. A. Omoyeni, and B. T. Aluko. Qualitative determination of chemical and nutritional composition of Cissuspetiolata leaves. Electronic Journal of Environmental, Agricultural and Food Chemistry,9 (2), 2010, 436 - 440.

[32]. G.G. E. Osuagwu. The effect of rate of application of poultry manure on the phenol, flavonoid and steroid potential of the leaves of Ocimumgratissimum. Journal of Sustainable Agriculture and the Environment, 10 (2), 2008,106 - 111.

[33]. G. G. E. Osuagwu and C. B. Akomas. (2013). Antimicrobial activity of three Species of Nigerian Pterocarpus(Jacq.). International Journal of Medicinal and Aromatic Plants 2(3), 2013, 178 - 183

[34]. G. G. E. Osuagwu and C. F. Eme. The phytochemical composition and antimicrobial activity Dialiumguineense, Vitexdoniana and Dennettiatripetala leaves. Asian Journal of Natural and Applied Sciences, 2(3), $2013,169-181$.

[35]. G. G. E. Osuagwu, I. C. Okwulehieand J. O. Emenike. Phytochemical and Mineral content of four Nigerian Pterocarpus species. Int. J. Mol. Med. Adv. Sci. 3(1), 2007, 6 - 11.

[36]. G. G. E. Osuagwu, H. O. Edeoga and A. N.Osuagwu. The influence of water (Drought) on the mineraland potential of the leaves of Ocimumgratissimum (L). Recent Research in $\quad$ Science and Technology, 2 (2), $2010,27-33$.

[37]. D.Pearson.Chemical Analysis of Food. (7th ed.)( Churchill Livingstone, Edinburg. UK, 1976) 575p.

[38]. J. Perrella, M. Berco, A. Cecuttand B. Bhavnani. Potential role of the interaction between equine estrogenlow density lipoprotein (LDL) and high density lipoprotein (HDL) in the prevention of coronary heart and neurodegenerative disease in postmenopausal women. Lipid in Health Disease, 2, $2003,4$.

[39]. R.Perulmalsamy and S. Ignacimuthu. Antibacterial activity of some folklore medicinal plants used used by tribals in western charts of India. JournalEthonopharmacology:69, 2000, 68-71.

[40]. D. Rein, J. Paglieroni, T. Wun, D. A.Pearson, H. H. Schmhz, R. Gossenlin and C. L. Keen. Cocoa inhibits platelet activation and function. Am. J. Clin. Nutr. 272, 2000, 30-35

[41]. Z. U. Shariff.ModernHerbalTherapyforCommonAilments.Nature Pharmacy Series (Volume1).(Spectrum Books Limited,Ibadan,Nigeria.In Association with Safari Books(Export)Limited,United Kingdom, 2001).pp 9-84.

[42]. R. Singh and S. K. Sawhney. (1988). Advances in Frontier Areas of Plant Biochemistry. (Prentice Hall in India, New Delhi, 1988),pp 487.

[43]. M. Subban, P. Annamalai and C. T. Arumugame. Phytochemical screening and Antimicrobial activity of the leaves of Memecylonumbellatum burm. F. JournalofAppliedPharmaceuticalScience 1(1), 2011, 42-45.

[44]. K. Valarmathy, P. S. Babu.And M. Abhilash. Antimicrobial activity of ethanolic extracts of varios plant leaves against selected microbial species. ElectronicJournalofEnvironmental AgriculturalandFoodChemistry, 9(8), 2010, 1378-1382.

[45]. F. Werner, P. Okemo and R. Ansorg. Antibacterial activity of East African Medicinal Plants. JournalEthnopharmacology,60, 1999, 79-84

[46]. World Health Organisation(WHO). General guidelines for Methodologies on research and evaluation of traditional medicine.World Health Organization, Geneva 9(8), 2001, 1378-1382

[47]. M. Zhu, T. D. Philipson, P. M.Greengrass, R. Bowmey and T. Cal. Plant polyphenols: Biological active compounds of Nonselective binders to protein. Phytochemistry, 44, 1997, 441- 447. 